\title{
Cuba's Basic Units of Cooperative Production ${ }^{1}$
}

José Alvarez ${ }^{2}$

On October 28, 2000, U.S. President Bill Clinton signed the Trade Sanctions Reform and Export Enhancement Act (TSRA) which allowed U.S. firms to sell food and agricultural products to Cuba and other countries. However, the Cuban government did not purchase any of these products until December of 2001 following the devastating damage caused by Hurricane Michelle to important agricultural areas in November of that year.

Cuban purchases from U.S. firms amounted to $\$ 4.319$ million in 2001, \$138.635 million in 2002, and $\$ 256.9$ million in 2003. Cuba became the 35 th most important food and agricultural export market for the United States in 2003, up from last (226th) in 2000. Actual purchases and pending contracts in the first-half of 2004 are at a pace to move Cuba into the top 20 most important markets of U.S. food and agricultural exports. Furthermore, because current U.S. legislation requires that all Cuban purchases from the United States must be conducted on a cash basis, the lack of credit risk associated with these sales makes Cuba one of the most attractive export markets for U.S. firms.

Anticipating changes in U.S.-Cuba trade relations, the Food and Resource Economics
Department at UF/IFAS initiated a research initiative on Cuba in 1990, including a 1993 collaborative agreement with the University of Havana, which has lasted to this day. (Most of the resulting publications can be found at http://www.cubanag.ifas.ufl.edu). We reiterate that our role as investigators is to provide the best available information and analyses from which rational decisions can be made. The reports included in this series intend to address the increasing level of interest in the Cuban market for food and agricultural products among U.S. firms and to assist them in becoming more familiar with that market. The complete list of documents in this series can be found by conducting a topical search for "Cuba" at http://edis.ifas.ufl.edu, or under "Additional Information" at the end of this document.

\section{Introduction}

One of the most important policies of the 1990s was perhaps terminating the state monopoly on land to establish the Basic Units of Cooperative Production (Unidades Básicas de Producción Cooperativa, UBPCs) on those lands. This change is especially significant from a philosophical point of view when one considers that Fidel Castro had consistently referred to state farms and CPAs as

1. This is EDIS document FE487, a publication of the Department of Food and Resource Economics, Florida Cooperative Extension Service, UF/IFAS, University of Florida, Gainesville, FL. Published July 2004. Please visit the EDIS website at http://edis.ifas.ufl.edu.

The author would like to thank the University Press of Florida (http://www.upf.com) for permission to reproduce material from the book Cuba's Agricultural Sector (Alvarez, 2004).

2. José Alvarez, Professor, Department of Food and Resource Economics, Everglades Research and Education Center, Belle Glade, FL, Florida Cooperative Extension Service, UF/IFAS, University of Florida, Gainesville, FL.

The Institute of Food and Agricultural Sciences is an equal opportunity/affirmative action employer authorized to provide research, educational information and other services only to individuals and institutions that function without regard to race, color, sex, age, handicap, or national origin. For information on obtaining other extension publications, contact your county Cooperative Extension Service office. Florida Cooperative Extension Service/Institute of Food and Agricultural Sciences/University of Florida/Christine Taylor Waddill, Dean. 
"superior forms of agricultural production." This fact sheet explains how these new forms of agricultural organization were established, how they work, and how they have performed in the ensuing years.

\section{Establishment and Organization}

On September 20, 1993, the Council of State enacted Law-Decree No. 142 establishing the Basic Units of Cooperative Production on state lands formerly organized as state farms (Gaceta, 1993, p. 15). Article 1 states that the activity of the UBPCs will be based on the following principles:

- linking man to the land.

- providing self-sufficiency for the workers' collective and their families through cooperative efforts and improved living conditions.

- achieving strict relationship between workers' earnings and production results.

- achieving self-sufficiency in the productive process through management autonomy and administration resources.

Article 2 establishes that the UBPCs will:

- have the usufruct of the land for an indefinite period of time.

- be the owners of their production.

- sell their production to the state through the enterprise or in the manner the state decides.

- pay insurance premiums.

- manage their bank accounts.

- purchase the fundamental means of production on credit.

- collectively elect its leadership who will render periodic accounts to its members.

- fulfill the corresponding fiscal responsibilities as their contribution to the general expenditures of the Nation.
By August 2, 1994, 2,643 sugarcane and non-sugarcane UBPCs had been established, with a total area of 2.96 million hectares and more than 257,000 members. This represented approximately $50 \%$ of the total land area in state hands, with $93.5 \%$ of state cane area going to cane UBPCs and $29 \%$ of state non-cane area allocated to non-cane UBPCs. Average UBPC size was 1,125 hectares, with 97 members per UBPC, or 11.6 hectares per worker (CEE, 1994, p. 2). In 1994, there were also 383 sugarcane CPAs and 185 CPAs of miscellaneous crops, with a total area of 5,872 hectares and 14,580 hectares, respectively (Polo Científico, n.d., pp. 9, 10). This resulted in a dramatic change in the shares of agricultural lands between the state and nonstate sectors.

One indication of the magnitude of the change is the difference in average farm size between state enterprises in 1990 and UBPCs in 1994 (one year after their establishment). Although the data indicate that the average UBPC was less than $10 \%$ of the size of the average state farm, González Jordán (1995, p. 91) believes that the average UBPC size was still too large and may be the reason for their early low productive and economic efficiencies.

The Cuban National Bank lends money to UBPCs for two major activities: production and investment. Production credits have a maximum payback period of 18 months, with payments made according to the periods when sales take place. In the case of investment loans, the payback period cannot surpass the lowest level of the useful life of the asset and a set number of years based on the life of the crop or the activities performed. For both types of credits, the maximum amount to be loaned cannot exceed $80 \%$ of the estimated value of the collateral. Interest rates charged are $4 \%$ for current loans, $5 \%$ for extended loans, and $6 \%$ for overdue loans. Loans for housing carry a $2 \%$ interest rate in mountainous areas and $3 \%$ in other areas of the country (Banco Nacional, n.d.)

For more information on organization, the incentives system, and the differences between UBPCs and CPAs, as they appear in Alvarez and Messina (1996), please visit: http://lanic.utexas.edu/la/ca/cuba/asce/cuba6/ 28alvmess.fm.pdf. 


\section{Economic and Social Performance}

First-Year Performance

In general, the first-year performance was disappointing. There were, however, exceptions to the rule. Deere (1995, p. 15) indicates that, as early as 1994, sugarcane UBPCs were performing at higher levels of efficiency than the former state farms. She cites the example of the 23 UBPCs linked to the large Majibacoa Agro-Industrial Complex in the province of Las Tunas generating profits in 1994. She states that, "when the land was managed as a state farm, the cane operations of this complex were generating an annual loss of two-million pesos" (p. 15).

Needless to say, Deere acknowledges that only $9 \%$ of the UBPCs performed well nationally.

Data compiled by Nova González (1995, p. 68) from official Cuban sources, show the relative profitability of state farms, Work Youth Army (EJT), UBPC, and CPA for 13 commodities (sweet potato, taro, cassava, banana, plantain, tomato, onion, garlic, pepper, pumpkin, rice, bean, and corn). The figures give additional evidence of the poorer performance of state farms and UBPCs relative to other types of agricultural organizations. For example, CPAs showed the highest net revenues in six of the 13 commodities analyzed and second-highest net revenues in two of them. EJTs showed the highest net revenues for four commodities and second-highest net revenues in seven of them. The rankings for state farms were two and four, respectively, and the rankings for UBPCs were one and zero, respectively. In addition, in the same 13 commodities, costs of production were lower for independent (private) farms than for CPAs and state farms. Private farms and CPAs had the lowest costs of production in three commodities. Private farms had the lowest costs in the remaining commodities, followed by CPAs and with state farms a distant last. Costs of production for all 13 crops in state farms were much higher than those of private farmers. Growing these crops on state farms does not make economic sense since they are much more expensive than CPAs and private farms.

For additional comments on the early performance of the UBPCs, as it appears in Alvarez and Messina (1996), please visit: http://lanic.utexas.edu/la/cb/cuba/asce/cuba6/ 28alvmess.fm.pdf.

\section{Subsequent Performance}

Several sources relating to different years after 1994 clearly indicate that UBPCs were not performing appreciably better. Some examples include:

- Of the 1,210 existing UBPCs, only $76(6.3 \%)$ reported profits in 1996 (Financial, 1997, p. 8).

- Of the 737 UBPCs devoted to livestock production, only 15\% were profitable in 1996. Crop diversification has been recommended as the means to increase profitability (Nova González, 1997).

- It was estimated that more than $85 \%$ of the sugarcane UBPCs were unprofitable while $80 \%$ of the livestock UBPCs were profitable in 1997. In addition, around $50 \%$ of the UBPCs owed money to Cuba's National Bank (Nova González, 1998, pp. 44, 46).

- Figures reported by Nova González (2003, p. 10) seem to indicate that profitability has improved since 1998 for most types of UBPCs. The best performers include those devoted to swine, livestock, rice, citrus, and other fruits.

Because of the preponderance of sugarcane UBPCs, they deserve a more complete discussion of performance. They were measured using selected variables from their establishment in the 1993-1994 season through the 2000-2001 season. The data show a sharp decrease in both the number of sugarcane UBPCs and UBPC members, which may be indicative of a trend toward concentration. Profitable sugarcane UBPCs went from $71 \%$ in the first season to $6 \%$ in the third season. After that year, they reported sharp increases in profitability until a sudden decrease in 2001. The cost of growing sugarcane increased tremendously during the first three seasons (increasing by $108 \%$ from the first to the fourth season) and declined thereafter. Finally, except for the 1993-1994 and 1999-2000 seasons, cost of production exceeded value of production (Sulroca Domínguez et al., 2000; Nova González, 2003, p. 26). 
Nova González (2001, p. 12) has wisely pointed out that the success or failure of sugarcane production is determined by the UBPCs since they account for $74 \%$ of total production. It is in those units where efforts should be concentrated.

Performance of non-sugarcane UBPCs was evaluated by Nova González $(2000 ; 2003)$ for the 1994-2003 period. Profitable UBPCs ranged from $29 \%$ in 1996 to $71 \%$ in 2000. Except for the last two years, more than $50 \%$ of the cooperatives were in the red during the study period.

At the beginning of 2002, meetings were held in every province by the Communist Party to evaluate the UBPCs' performance. According to a report issued by CubaNet on January 14, 2002, party officials concluded that most UBPCs are bankrupt. Participants at the meetings blamed a series of factors for their poor results. Some of those factors include sluggish payment for actual production as opposed to salary, instability in the growth of cane fields, lack of attention to all crops, low productivity, and inadequate attention to the needs of workers. Participants held administrators responsible for the disaster. In response, officials expressed the opinion that the times demanded definite solutions for the UBPCs. Some of these factors were discussed earlier in this fact sheet when describing the results of two official surveys conducted more than one year after the UBPCs establishment. The provincial meetings revealed that, seven years later, solutions to those early problems had yet to be found.

Are UBPCs still performing poorly only because of problems not solved after one decade? Are these poor results a reiteration of inefficiencies inherent to this type of agricultural organization under a socialist system? What benefits have the UBPCs brought to Cuban agriculture? The second question will be answered in another fact sheet (EDIS FE488). Although some answers to the first and third questions can be found scattered in several parts of this fact sheet, here is a summary of a long list of factors listed in four publications by official Cuban economists.

Some of the changes and positive results that UBPCs have brought to Cuban agriculture appear in Pérez Villanueva (2000, p. 87):
- a gradual recovery of Cuba's agricultural production, except in sugarcane and cattle.

- a substantial reduction in subsidies granted for agricultural losses (e.g., from 1,800 million pesos in 1994 to 718 millions in 1997).

- a slight improvement in the rational use of resources such as inputs, raw materials, fuels, and others.

- a restructuring of the overall average size of agricultural units (i.e., a reduction in the area of immense state farms).

- a change in the management of agricultural production and in the method of workers' remuneration from wages to distribution of profits.

- a better use of agricultural areas and the recuperation of cultivated areas.

- a new model of work incentives.

- a democratization of the productive process due to an increasing participation of producers in the decision-making process.

- a new model of self-management, diversification of property regimen, and new actors in the agricultural scene.

Factors contributing to the deficiencies and inefficiencies of the UBPCs, as enumerated by Nova González (1998, pp. 45-46) and Pérez Villanueva (2000a, p. 87), include:

- the autonomy issue-this appears time and again when discussing UBPCs. The strong influence of the state still remains in nearly all cases. In cases where some autonomy does appear to exist, it is extremely limited. The lack of autonomy hinders UBPCs' control of how to use their resources and the magnitude and location of their sales. The lack of a competitive market forces UBPCs to pay high prices for the inputs and services sold by the state.

- the decrease in UBPCs' labor force, mainly due to better employment alternatives, no guarantees of food from self-provisioning plots, limited housing, and insufficient economic stimuli. 
- the high debt UBPCs still maintain with the Central Bank after the initial purchase of machinery and equipment from the state (which have deteriorated).

Rodríguez Castellón (1997) and Wong (1998) share very similar opinions concerning the factors that need immediate implementation for the future development of these agricultural production units:

- clear definitions in the UBPC statutes concerning the entry and exit of each member (new members acquire an indivisible debt which disappears when they leave the cooperative).

- explicit delineation of the frontiers between the activities of the state and the UBPCs.

- changes in the internal control of the economic and financial activities now exerted by the board of directors, with exogenous control exerted by the state.

- an explicit mandate for the payment of benefits that, although now implicit in the remuneration according to productive results, has not been accomplished successfully.

- an expansion of the cooperative concept from the agricultural activities to the selling and marketing of their products.

- a decrease in the vertical ties and a sharp increase in the horizontal relationships between the cooperatives and other economic entities.

- an increase in the awareness of members about their ownership rights that eventually would eliminate the paternalistic and administrative practices that characterized the centralized decision-making model.

\section{Conclusions and Policy Implications}

The issues examined in this fact sheet convey important policy implications. It is evident that the remaining state farms either are still unprofitable or have higher costs of production than other types of agricultural organizations, especially private farms. After analyzing the differences between the state and nonstate sectors one has to wonder about the reasons for the continued existence of some state farms. There is speculation that some of them are being held by the government as potential joint-venture operations or economic associations. Or, simply it may be that, since the majority of state farms have already been converted into UBPCs, the incentive to complete the process has decreased. Nevertheless, the fact that the majority of state farms have been broken up into UBPCs is a clear indication of the commitment on the part of the Cuban government to this fundamental policy change.

The degree of autonomy of the new cooperatives is an issue that has been debated in Cuba for many years now. The degree of control and autonomy that UBPC members have in their operation is certainly limited, compared to what farmers in market economies have. However, UBPCs are still a substantial improvement over the large state farms. As a result, UBPC members have a new sense of stewardship toward the land and they recognize UBPCs as a mechanism to improve their personal well-being. These are important incentives that need to be reinforced. That has not happened.

The decision to dismantle the state farms into UBPCs and the creation of the agricultural markets (EDIS FE488) would appear to have created a window of opportunity for the Cuban leadership to improve domestic agricultural production and food availabilities. Obstacles still exist that hinder the efficient operation of these new institutions in Cuba. Such obstacles are inherent to the system and independent of input shortages. For example, there is little incentive to produce beyond $100 \%$ of the established production goal since $80 \%$ of any surplus beyond that amount is sold to the state agency at very low prices. The state monopoly on inputs, services, and commercialization hinders food availability. Even if these inherent obstacles are removed, chronic shortages of fertilizers, pesticides, and fuel oil will restrict the ability of the agricultural sector to respond in dramatic fashion. The obstacles, especially the restrictive input and output markets, must be removed if the Cuban government wants to increase agricultural output and food accessibility. 


\section{References}

Alvarez, José. 2004. Cuba's Agricultural Sector. Gainesville, FL: University Press of Florida.

Alvarez, José, and William A. Messina, Jr. 1996. Cuba's New Agricultural Cooperatives and Markets: Antecedents, Organization, Early Performance and Prospects. Cuba in Transition 6: 175-195.

Banco Nacional de Cuba. n.d. El Crédito Bancario a las Unidades Básicas de Producción Cooperativa Cañeras. La Habana: División Banca de Crédito y Comercio.

Comité Estatal de Estadísticas (CEE). 1994. Anuario Estadístico de Cuba. La Habana: Editorial Estadística.

Deere, Carmen Diana. 1995. The New Agrarian Reforms. NACLA Report on the Americas 29 (2, September-October): 13-17.

Gaceta Oficial de la República de Cuba. 1993. La Habana, September 21.

González Jordán, Benjamín. 1995. La Agricultura Cubana: Un Balance Crítico. Economía y Desarrollo118 (2, December): 81-97.

Nova González, Armando. 1995. Mercado Agropecuario: Factores que Limitan la Oferta. Cuba: Investigación Económica 3 (October): 63-72.

Nova González, Armando. 1997. Las UBPC Ganadera en Busca de la Rentabilidad. Economics Press Service 10, 17, pp. 22-24, September 15.

Nova González, Armando. 1998. Las Nuevas Relaciones de Producción en la Agricultura. Cuba: Investigación Económica 4 (1, January-March): 39-56.

Nova González, Armando. 2000. La Economía Cubana en la Década de los 90. Enfoques , Segunda Quincena ( February).

Nova González, Armando. 2001. Las Unidades Básicas de Producción Cooperativa y las Granjas Cañeras Entre 1993 y el 2000. Ciudad de la Habana:
Centro de Estudios de la Economía Cubana, Universidad de la Habana (March).

Nova González, Armando. 2003. La UBPC y el Cooperativismo en la Agricultura Cubana, 1993-2001. Paper presented at the annual meeting of the Latin American Studies Association, Dallas, Texas, March 27-29.

Pérez Villanueva, and Omar Everleny. 2000. La Reestructuración de la Economía Cubana. El Proceso en la Agricultura. In La Ultima Reforma Agraria del Siglo - La Agricultura Cubana Entre el Cambio y el Estancamiento, edited by Hans-Jürgen Burchardt, pp. 71-105. Caracas, Venezuela: Editorial Nueva Sociedad.

Polo Científico de Humanidades. n.d. Grupo: Estudios Socio-económicos de Producción Cooperativa y Campesina. La Habana: Instituto Superior de Ciencias Agropecuarias de la Habana (ISCAH).

Rodríguez Castellón, Santiago. 1997. La Agricultura Cubana en el Marco de la Reestructuración Económica - La Transformación de la Agricultura Cubana a Partir de 1993. University of Hannover.

Sulroca Domínguez, Federico, Eduardo Lamadrid Martínez, Odalys López, and Luis García Sacerio. 2000. Las Unidades Básicas de Producción Cooperativa (UBPC) en la Agricultura Cubana. Paper presented at the international seminar on cooperatives, University of Havana, (February 3).

Wong, Angel Bu. 1998. La Cooperativización: Su Desarrollo en Cuba. Cuba: Investigación Económica 4 (1, January-March): 95-109. 1997. Financial Measures to Boost Cane Planting. Business Tips on Cuba 4 (5, May): 8.

\section{Additional Information}

Below is a list of the fact sheets in this series on Cuban Agriculture. They can be accessed by clicking on the highlighted links:

- FE479 - Cuban Agriculture Before 1959: The Political and Economic Situations 
- FE480 - Cuban Agriculture Before 1959: The Social Situation

- FE481 - Transformations in Cuban Agriculture After 1959

- FE482 - Overview of Cuba's Food Rationing System

- FE483 - The Issue of Food Security in Cuba

- FE484 - Acopio: Cuba's State Procurement and Distribution Agency

- FE485 - Antecedents of the Cuban Agricultural Policies of the 1990s

- FE486 - Chronology of Cuban Reform Policies with Emphasis on Agriculture, 1993-1995

- FE487 - Cuba's Basic Units of Cooperative Production

- FE488 - Cuba's Agricultural Markets

- FE489 - Environmental Deterioration and Conservation in Cuban Agriculture

- FE490 - The Potential Correlation between Natural Disasters and Cuba's Agricultural Performance 